\title{
Determination of Palladium in Alloy by Flame Atomic Absorption Spectrometry after Preconcentration of Its Iodide Complex on Amberlite XAD-16
}

\author{
Adalet TunÇELI and A. Rehber TüRKER \\ Gazi Üniversitesi, Fen Edebiyat Fakültesi, TR-06500 Ankara, Turkey
}

\begin{abstract}
In this study, a method was developed for preconcentration and determination of palladium in alloys with flame atomic absorption spectrometry (FAAS). For preconcentration, a column containing Amberlite XAD-16 has been used and the preconcentration conditions have been investigated as a function of $\mathrm{pH}$, elution solution, complexing agent, volume of sample solution and flow rate of the sample solution. The effect of some matrix elements, such as $\mathrm{Fe}, \mathrm{Cu}, \mathrm{Ni}, \mathrm{Na}, \mathrm{K}, \mathrm{Ca}$ and $\mathrm{Mg}$, on the recovery of palladium has also been investigated. At optimum conditions determined experimentally, the recovery of palladium was found as to be $98.03 \pm 0.08 \%$. For the determination of the adsorption behavior of the resin, the adsorption isotherm of palladium has been studied, The binding equilibrium constant $\left(430 \mathrm{l} \mathrm{mol}^{-1}\right)$ and the adsorption capacity (35.6 $\mathrm{mg} \mathrm{g}^{-1}$ ) have also been calculated. The proposed method has been applied to the standard reference material (SRM) and palladium has been determined with the relative error 5.68\%. The detection limit of the analyte has been found to be $0.051 \mathrm{mg} \mathrm{l}^{-1}$.
\end{abstract}

(Received May 31, 1999; Accepted October 18, 1999

Palladium is one of the precious metals. In the field of analytical science, palladium is used as a matrix modifier for the determination of several metals by electrothermal atomic absorption spectrometry. ${ }^{1,2}$ Owing to its corrosion resistance nature and alloying ability, palladium is an important element in metallurgy. Its alloys are used in dental and medicinal devices and in jewelry manifacture. Moreover, palladium is used in automobile catalysts together with $\mathrm{Pt}$ and $\mathrm{Rh}$. They oxide specific toxic components such as carbon monoxide, hydrocarbons and also various nitrous oxides in hot gases as they pass through the exhaust system. ${ }^{3,4}$

Palladium can be determined by expensive instruments such as inductively coupled plasma atomic emission spectrometer, $3,5,6$ glow discharge mass spectrometer ${ }^{4}$ and electrothermal atomic absorption spectrometer ${ }^{1,2,7}$ either with or without separation and preconcentration steps. Palladium is widely determined spectrophotometrically after preconcentration by extraction, adsorption or reversed phase high-performance liquid chromatography. ${ }^{8-20}$

Spectrophotometric determination is normally simple, but solvent extraction of palladium is difficult because of slow extraction rates. Because the complexing of palladium is difficult at room temperature, heating the solution or using a catalyst can be necessary. In addition, any excess of reagent is also extracted into the organic phase causing high reagent blanks. For such reasons, many improvement studies have been done and many complexing agents have been tested for increasing the extractibility of palladium. ${ }^{9-12}$

Flame atomic absorption spectrometry (FAAS) is a simple and cheap technique for the determination of trace amounts of palladium. But, because of the low abundance of palladium in

\footnotetext{
† To whom correspondence should be addressed.

E-mail: rturker@quark.fef.gazi.edu.tr
}

many samples, the direct determination of it by FAAS is often difficult. Moreover, with the air-acetylene system, severe depression of absorbance occurs in the presence of iridium and nickel and smaller but noticeable depression in the presence of iron, chromium and platinium. ${ }^{21}$ In order to prevent these interferences and increase sensitivity, generally separation and preconcentration of palladium from sample matrix are necessary. For this purpose, extraction, ${ }^{22}$ ion exchange ${ }^{23}$ or adsorption $^{24}$ techniques have been used.

In this study, adsorption has been used as an enrichment technique. Because of the purity and good adsorption properties, Amberlite XAD-16 resin, which has the largest surface area of Amberlite XAD series, was used as adsorbent. The various parameters such as $\mathrm{pH}$, elution solution, volume of sample, complexing agent, interfering ions and flow rate have been evaluated. The procedure developed has been succesfully employed for the trace determination of palladium in alloys.

\section{Experimental}

\section{Apparatus}

A Philips PU 9285 flame atomic absorption spectrometer was used for the determination of palladium; it was equipped with a deuterium lamp background correction, a hollow cathode lamp and an air-acetylene burner. The instrumental parameters were as follows: wavelength: $247.6 \mathrm{~nm}$, lamp current: $11.2 \mathrm{~mA}$, bandpass: $0.5 \mathrm{~nm}$ and fuel flow rate: $1.11 \mathrm{~min}^{-1}$. All $\mathrm{pH}$ measurements were made with a Consort digital $\mathrm{pH}$ meter and combined glass electrode.

\section{Reagents}

Unless otherwise specified, all reagents used were of analytical reagent grade. Deionized and distilled water was 
used throughout. Stock palladium solution $\left(1000 \mathrm{mg} \mathrm{l}^{-1}\right)$ was prepared by dissolving $1.6661 \mathrm{~g}$ of $\mathrm{PdCl}_{2}$ and making up to $1000 \mathrm{ml}$ with water. Standard $\left(100 \mathrm{mg} \mathrm{l}^{-1}\right)$ and spiked solutions were prepared by diluting the stock solution to appropriate volumes. Other solutions used were prepared from the analytical reagent grade salts.

Amberlite XAD-16 resin (Rohm and Haas, Philadelphia, PA, USA; surface area $800 \mathrm{~m}^{2} \mathrm{~g}^{-1}$; wet mesh size 20 - 60) was used after washing with methanol and $1 \mathrm{~mol} \mathrm{l}^{-1}$ hydrochloric acid and deionized and distilled water and dried at $60^{\circ} \mathrm{C}$.

\section{Column preparation}

A glass column (30 mm length and $10 \mathrm{~mm}$ i.d.) containing 0.2 $\mathrm{g}$ of adsorbent with a glass-wool plug over its stopcock was used. Another plug of glass-wool was placed on the resin in order to prevent the change of bed height. Regeneration of the resin was performed with passing $1 \mathrm{~mol} \mathrm{l}^{-1}$ hydrochloric acid and deionized and distilled water before using the column.

\section{General preconcentration procedure}

$0.25 \mathrm{ml}$ of standard palladium solution $\left(100 \mathrm{mg} \mathrm{l}^{-1}\right)$ was taken into a $100 \mathrm{ml}$ volumetric flask and $1.5 \mathrm{ml}$ of $0.5 \mathrm{~mol} \mathrm{l}^{-1}$ potassium iodide solution was added for complexing. The total volume was completed to $100 \mathrm{ml}$ with deionized and distilled water. The $\mathrm{pH}$ of the solution was adjusted to 2 with hydrochloric acid. After adjusting $\mathrm{pH}$, the solution was passed through the column at an optimum flow rate of about $1 \mathrm{ml}$ $\mathrm{min}^{-1}$. Firstly, $5 \mathrm{ml}$ of $1 \mathrm{~mol} \mathrm{l}^{-1}$ potassium cyanide was used for elution of retained palladium on the column. Then, $5 \mathrm{ml}$ of $10 \%(\mathrm{v} / \mathrm{v})$ hydrochloric acid solution was used for the second elution.

Warning: The evolution of gaseous HCN may happen if $\mathrm{KCN}$ is mixed with $\mathrm{HCl}$ solution. So, this method should be applied carefully and precautions should be taken to avoid any appearance of $\mathrm{HCN}$.

First and second eluents were collected together into a $10 \mathrm{ml}$ volumetric flask and aspirated to the flame. Palladium content was determined by FAAS and the recovery of palladium was calculated from the ratio of the concentration found by FAAS to that calculated theoretically.

\section{Sample preparation}

To evaluate the applicability and accuracy of the proposed method, a standard reference material (SRM) containing palladium should be analyzed. Because we have no SRM containing palladium, we used a lead-based alloy as a SRM by adding a known amount of palladium to it. For preperation of this spiked SRM, approximately $0.5 \mathrm{~g}$ of sample was weighed accurately into a beaker and $2.5 \mathrm{ml}$ of standard palladium solution $\left(100 \mathrm{mg} \mathrm{l}^{-1}\right)$ and $10 \mathrm{ml}$ of $30 \%(\mathrm{v} / \mathrm{v})$ nitric acid solution were added to the sample; this mixture was heated. Firstly, digestion occurred and then a precipitate containing tin and antimony oxides appeared. Ten milliliters of water was added and we continued to heat the mixture for $10 \mathrm{~min}$. The precipitate was filtered through a fine filter paper and washed. Palladium was determined in the filtrate by applying the general procedure. Some interferences may occur during the preconcentration step. To prevent these interferences, some chemical treatments have been made. These are as follows: Nitric acid reduces to nitrous acid during the digestion and nitrous acid oxides iodide to iodine when potassium iodide is added as a complexing agent. At the same time, lead ions precipitate as lead iodide with the addition of potassium iodide.

Ammonium sulfate (about $2 \mathrm{~g}$ ) was used for reducing nitrous acid to nitrogen and for precipitation of lead as lead sulfate.
Table 1 Effect of elution solutions on the recovery of palladium

\begin{tabular}{|c|c|}
\hline Solution & $\begin{array}{l}\text { Recovery of } \\
\text { Pd, \% }\end{array}$ \\
\hline $10 \mathrm{ml}$ of $6 \mathrm{~mol} \mathrm{l}^{-1} \mathrm{NH}_{3}$ & 28.0 \\
\hline $10 \mathrm{ml}$ of $1 \mathrm{~mol} \mathrm{l}^{-1} \mathrm{NaNO}_{2}$ & 47.4 \\
\hline $10 \mathrm{ml}$ of $1 \mathrm{~mol} \mathrm{l}^{-1} \mathrm{HCl}$ & 77.6 \\
\hline $10 \mathrm{ml}$ of $1 \mathrm{~mol} \mathrm{l}^{-1} \mathrm{KCN}$ & 86.6 \\
\hline $10 \mathrm{ml}$ of $1 \mathrm{~mol} \mathrm{l}^{-1} \mathrm{KI}$ & 86.7 \\
\hline $\begin{array}{c}5 \mathrm{ml} \text { of } 0.5 \mathrm{~mol} \mathrm{l}^{-1} \mathrm{KI} \text { and } \\
5 \mathrm{ml} \text { of } 1 \mathrm{~mol} \mathrm{l}^{-1} \mathrm{HNO}_{3}\end{array}$ & 71.0 \\
\hline $\begin{array}{l}5 \mathrm{ml} \text { of } 0.5 \mathrm{~mol} \mathrm{l}^{-1} \mathrm{KCN} \text { in } \\
1 \mathrm{~mol}^{-1} \mathrm{HNO}_{3} \text { and } 5 \mathrm{ml} \text { of } 1 \mathrm{~mol} \mathrm{l}^{-1} \mathrm{HNO}_{3}\end{array}$ & 72.4 \\
\hline $\begin{array}{l}5 \mathrm{ml} \text { of } 0.5 \mathrm{~mol} \mathrm{l}^{-1} \text { thiourea in } 1 \mathrm{~mol} \mathrm{l}^{-1} \mathrm{HNO}_{3} \\
\text { and } 5 \mathrm{ml} \text { of } 1 \mathrm{~mol} \mathrm{l}^{-1} \mathrm{HNO}_{3}\end{array}$ & 77.0 \\
\hline $\begin{array}{l}5 \mathrm{ml} \text { of } 0.5 \mathrm{~mol} \mathrm{l}^{-1} \mathrm{KBr} \text { in } 1 \mathrm{~mol}^{-1} \mathrm{HNO}_{3} \text { and } \\
5 \mathrm{ml} \text { of } 1 \mathrm{~mol} \mathrm{l}^{-1} \mathrm{HNO}_{3}\end{array}$ & 77.0 \\
\hline $10 \mathrm{ml}$ of $0.5 \mathrm{~mol} \mathrm{l}^{-1} \mathrm{KCN}$ in $1 \mathrm{~mol} \mathrm{l}^{-1} \mathrm{HNO}_{3}$ & 83.8 \\
\hline $\begin{array}{l}5 \mathrm{ml} \text { of } 1 \mathrm{~mol} \mathrm{l}^{-1} \mathrm{KCN} \text { in } 1 \mathrm{~mol}^{-1} \mathrm{HNO}_{3} \text { and } \\
5 \mathrm{ml} \text { of } 2 \mathrm{~mol} \mathrm{l}^{-1} \mathrm{HNO}_{3}^{-\mathrm{a}}\end{array}$ & 91.4 \\
\hline $\begin{array}{l}5 \mathrm{ml} \text { of } 1 \mathrm{~mol} \mathrm{l}^{-1} \mathrm{KCN} \text { in } 1 \mathrm{~mol} \mathrm{l}^{-1} \mathrm{HNO}_{3} \text { and } \\
5 \mathrm{ml} \text { of } 1 \mathrm{~mol} \mathrm{l}^{-1} \mathrm{HNO}_{3}^{-\mathrm{a}}\end{array}$ & 93.3 \\
\hline $\begin{array}{l}5 \mathrm{ml} \text { of } 0.5 \mathrm{~mol} \mathrm{l}^{-1} \mathrm{KCN} \text { in } 1 \mathrm{~mol}^{-1} \mathrm{HNO}_{3} \\
\text { and } 5 \mathrm{ml} \text { of } 1 \mathrm{~mol} \mathrm{l}^{-1} \mathrm{HNO}_{3}{ }^{\text {a }}\end{array}$ & 93.6 \\
\hline $5 \mathrm{ml}$ of $1 \mathrm{~mol} \mathrm{l}^{-1} \mathrm{KCN}$ and $5 \mathrm{ml}$ of $10(\mathrm{v} / \mathrm{v}) \% \mathrm{HCl}$ & 97.9 \\
\hline
\end{tabular}

a. These solutions were used in order to elute palladium as iodide complex In the case of two eluents, they were used one after the other.

$$
\begin{aligned}
& \mathrm{HNO}_{2}+\mathrm{NH}_{4}{ }^{+} \longrightarrow \mathrm{N}_{2}+\mathrm{H}^{+}+2 \mathrm{H}_{2} \mathrm{O} \\
& \mathrm{Pb}^{2+}+\mathrm{SO}_{4}{ }^{2-} \longrightarrow \mathrm{PbSO}_{4} \downarrow
\end{aligned}
$$

Thus, formation of iodine and precipitation of lead iodide have been prevented. The precipitate of lead sulfate was filtered through the filter paper and washed carefully. The filtrate and washings were collected into a $100 \mathrm{ml}$ volumetric flask and the total volume was adjusted to $100 \mathrm{ml}$ with deionized and distilled water. This solution has been used as the stock sample solution. To $10 \mathrm{ml}$ of stock sample solution, $2 \mathrm{ml}$ of $0.5 \mathrm{~mol} \mathrm{l}^{-1}$ potassium iodide solution was added. The total volume was completed to $100 \mathrm{ml}$ with deionized and distilled water after adjusting the $\mathrm{pH}$ to 2. This solution was passed through the column and retained palladium was eluted by using $5 \mathrm{ml}$ of $1 \mathrm{~mol} \mathrm{l}^{-1}$ potassium cyanide and $5 \mathrm{ml}$ of $10 \%(\mathrm{v} / \mathrm{v})$ hydrochloric acid into a $10 \mathrm{ml}$ volumetric flask containing $0.5 \mathrm{ml}$ of $0.5 \%(\mathrm{~m} / \mathrm{v})$ copper solution. The same amount of copper solution was also added to each calibration solution in order to prevent the possible interelemental interferences of transition elements such as iron and nickel. ${ }^{25,26}$ This procedure was repeated for six solutions which were taken from the stock sample solution.

\section{Results and Discussion}

\section{Effect of hydronium ion concentration}

Hydronium ion concentration is one of the most important parameter affecting the preconcentration process. For this reason, firstly the effect of hydronium ion concentration of the sample solution has been investigated. Because the optimum values of the affecting parameters are not known at the begining of the experiments, pre-tests have been performed. For this purpose, $100 \mathrm{ml}$ of $0.25 \mathrm{mg} \mathrm{l}^{-1}$ standard palladium solution (as chloride) has been prepared and hydronium ion concentration has been adjusted to the desired values. After applying the column process, the retained palladium has been eluted by 10 


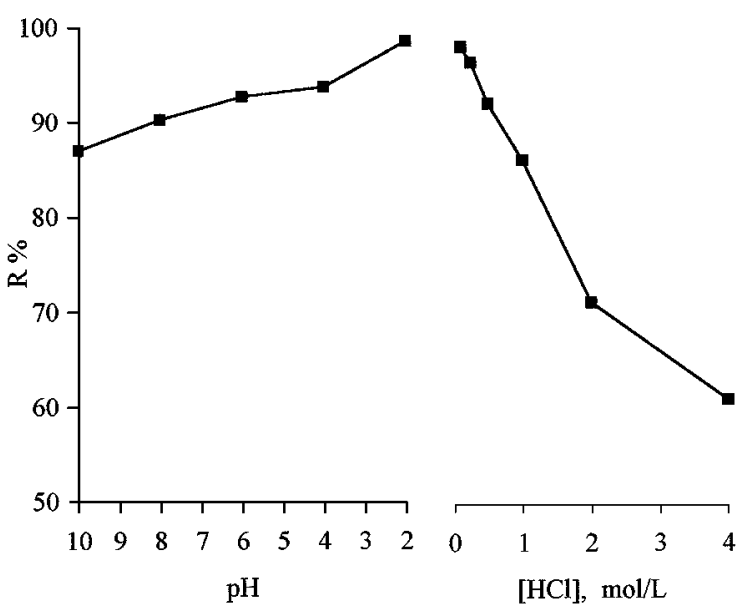

Fig. 1 Effect of hydronium ion concentration on the recovery of palladium: complexing agent, KI; eluent, $5 \mathrm{ml}$ of $1 \mathrm{~mol} \mathrm{l}^{-1} \mathrm{KCN}$ and $5 \mathrm{ml}$ of $10 \%(\mathrm{v} / \mathrm{v}) \mathrm{HCl}$ solutions; flow rate, $1 \mathrm{ml} \mathrm{min}^{-1}$.

$\mathrm{ml}$ of $1 \mathrm{~mol} \mathrm{l} \mathrm{l}^{-1} \mathrm{HCl}, 10 \mathrm{ml}$ of $\mathrm{NaNO}_{2}, 10 \mathrm{ml}$ of $\mathrm{NH}_{3}$ separately. As a result, maximum recovery $(c a .78 \%)$ has been obtained at about pH 2 (see first three value in Table 1). Then, other parameters described below have been investigated at this $\mathrm{pH}$ and the optimum values of the parameters have been determined. By using these optimum values (complexing agent: $\mathrm{KI}$, eluent solutions: $5 \mathrm{ml} 1 \mathrm{~mol} \mathrm{l}^{-1} \mathrm{KCN}$ and $5 \mathrm{ml} \mathrm{10 \% (v/v)}$ $\mathrm{HCl}$, flow rate: $1 \mathrm{ml} \mathrm{min}^{-1}$ ) the effect of hydronium ion concentration has been investigated again. The results are shown in Fig. 1. As can be seen, a quantitative recovery ( $c a$. $98 \%$ ) for palladium has been obtained at $\mathrm{pH} 2$.

\section{Effect of the type and volume of elution solutions}

A hundred milliliters of spiked solutions were prepared by dilution of $0.25 \mathrm{ml}$ of $100 \mathrm{mg} \mathrm{l}^{-1}$ palladium solution to $100 \mathrm{ml}$ and adjusting $\mathrm{pH}$ to 2 with hydrochloric acid solution. These solutions were passed through the column and ammonia, hydrochloric acid, potassium iodide, sodium nitrite, thiourea and potassium cyanide solutions were used to elute retained palladium as chloride complex (Table 1). As can be seen from Table 1, the maximum recovery $(\mathrm{ca} .87 \%)$ has been obtained by using $10 \mathrm{ml}$ of $1 \mathrm{~mol} \mathrm{l}^{-1}$ potassium iodide and $10 \mathrm{ml}$ of $1 \mathrm{~mol} \mathrm{l}^{-1}$ potassium cyanide separately.

\section{Effect of complexing agent}

Because of the insufficient recovery ( $c a .87 \%)$, we examined potassium iodide as a complexing agent in order to further increase the recovery of palladium. Because palladium is a soft Pearson metal, it forms a more stable anionic complex with iodide than with chloride. For this purpose, $1.5 \mathrm{ml}$ of $0.5 \mathrm{~mol} \mathrm{l}^{-1}$ potassium iodide was added to the palladium-spiked solution $\left(0.25 \mathrm{mg} \mathrm{l}^{-1}\right)$. Then the solutions were passed through the columns after adjusting the $\mathrm{pH}$ values of the solutions to $2-10$ with hydrochloric acid and potassium hydroxide solutions. The maximum recovery was obtained as $97.9 \%$ at $\mathrm{pH} 2$ by using firstly $5 \mathrm{ml}$ of $1 \mathrm{~mol} \mathrm{l}^{-1}$ potassium cyanide, and then $5 \mathrm{ml}$ of $10 \%(\mathrm{v} / \mathrm{v})$ hydrochloric acid solutions as an eluent. Therefore, potassium iodide was used as a complexing agent for subsequent experiments.

Effect of sample volume and analyte concentration

In order to determine the maximum applicable sample

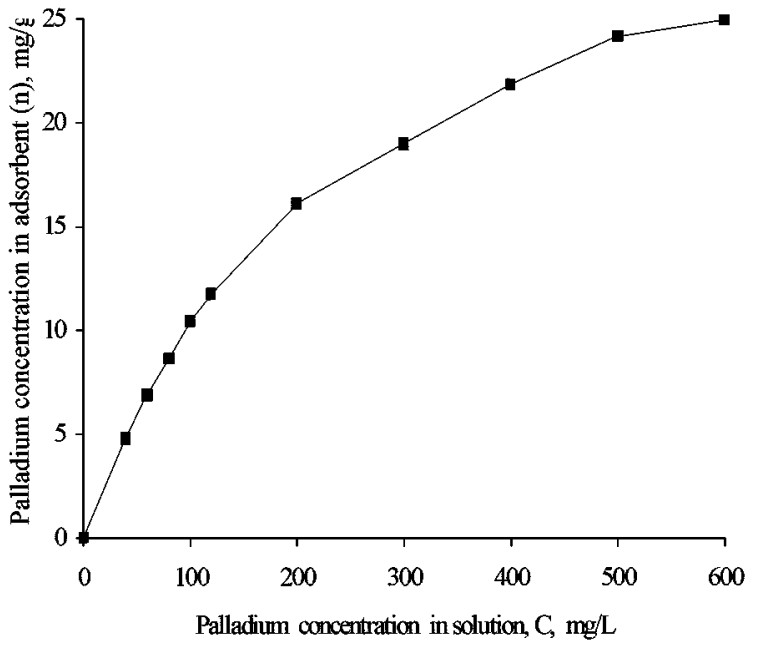

Fig. 2 Adsorption isotherm of XAD-16 for palladium.

volume, palladium was preconcentrated from volumes of 100 , 250, 500, 750 and $1000 \mathrm{ml}$ of sample solutions containing 0.25 , $0.10,0.05,0.033$ and $0.025 \mathrm{mg} \mathrm{l}^{-1}$ of palladium by applying the general procedure mentioned above. The recovery of palladium was approximately quantitative ( $c a .95 \%)$ up to sample volumes of $1000 \mathrm{ml}$. In this study, the elution volume was $10 \mathrm{ml}$ and the preconcentration factor was 100 . According to this result, 0.25 $\mathrm{mg} \mathrm{l}^{-1}$ palladium could be determined by the proposed preconcentrationmethod.

\section{Effect of flow rate of sample solution on sorption}

For this purpose, flow rates of $1,2.5$ and $5 \mathrm{ml} \mathrm{min}^{-1}$ were studied and recoveries of 98,72 and $61 \%$ were obtained as a mean of three replicates respectively. $1 \mathrm{ml} \mathrm{min}^{-1}$ was chosen for subsequent experiments.

\section{Precision of method}

The precision of this method was investigated at the optimum conditions mentioned above $\left(\mathrm{pH}: 2\right.$, flow rate: $1 \mathrm{ml} \mathrm{min}{ }^{-1}$, elution solution: $5 \mathrm{ml}$ of $1 \mathrm{~mol} \mathrm{l}^{-1}$ potassium cyanide and $5 \mathrm{ml}$ of $10 \%(\mathrm{v} / \mathrm{v})$ hydrochloric acid, complexing agent: potassium iodide) by performing succesive retention and elution cycles with $0.25 \mathrm{mg} \mathrm{l}^{-1}$ palladium solutions. The mean recovery for eight determinations was $98.03 \pm 0.08 \%$ at the $95 \%$ confidence level. As can be seen, the recovery was quantitative and the precision of the method is quite good, the relative standard deviation being about $4.1 \%$.

\section{Adsorption isotherm}

For the determination of the adsorption behavior of resin, the concentration of adsorbed palladium $(n)$ in $\mathrm{mg} \mathrm{g}^{-1}$ was studied as a function of palladium concentration $(C)$ in $\mathrm{mg} \mathrm{l}^{-1}$ (Fig. 2). As can be seen from Fig. 2, the adsorption isotherm conforms to the Langmuir equation. ${ }^{27}$ Capacity $\left(n_{\mathrm{m}}\right)$ of the resin for palladium was found to be $35.56 \mathrm{mg} \mathrm{g}^{-1}\left(0.33 \mathrm{mmol} \mathrm{g}^{-1}\right)$ and binding constant $K$ was found to be about $4301 \mathrm{~mol}^{-1}$ according to Langmuir equation, as given below by graphical treatment ${ }^{28}$ of the data (Fig. 3).

$$
\frac{C}{n}=\frac{1}{n_{\mathrm{m}} K}+\left(\frac{1}{n_{\mathrm{m}}}\right) C
$$

Effects of matrix elements

According to the literature, many elements, especially iron 


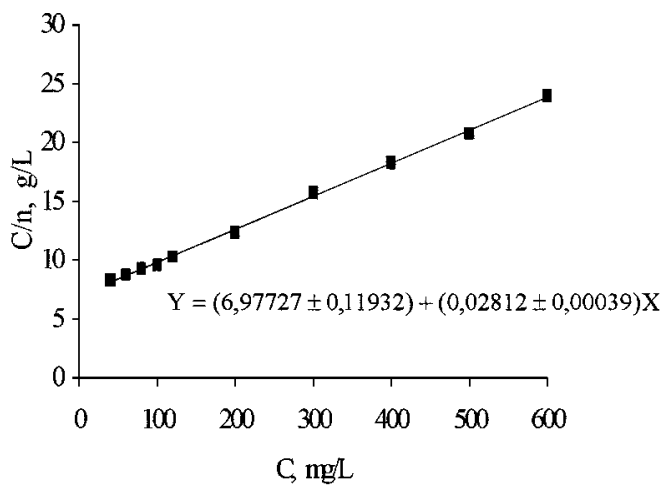

Fig. 3 Langmuir plot for palladium adsorption on XAD-16.

and nickel, depress the signal of palladium in air-acetylene flame. ${ }^{21,25}$ For this reason, the effects of $\mathrm{Fe}, \mathrm{Ni}, \mathrm{Cu}, \mathrm{Na}, \mathrm{K}, \mathrm{Ca}$ and $\mathrm{Mg}$ were investigated. For this purpose, palladium was determined in the presence of 1000-fold excess of matrix elements over palladium by using this proposed method.

Interferences were found in the presence of iron and copper when the preconcentration procedure developed was applied for palladium. For iodide reduces iron(III) to iron(II) and copper(II) to copper(I) in acidic medium when potassium iodide is added as a complexing agent to palladium solution in the presence of iron and copper.

$$
\begin{aligned}
& 2 \mathrm{Fe}^{3+}+2 \mathrm{I}^{-} \longrightarrow 2 \mathrm{Fe}^{2+}+\mathrm{I}_{2} \\
& \mathrm{Cu}^{2+}+2 \mathrm{I}^{-} \longrightarrow \mathrm{CuI} \downarrow+1 / 2 \mathrm{I}_{2}
\end{aligned}
$$

Because of the iodide deficiency, the soluble iodide complex of palladium can not form. A low signal was also obtained in the presence of nickel.

In order to eliminate the iron, copper and nickel interferences, EDTA solution was tested for each element as a masking agent. Sodium fluoride was also tested for iron interference. As a masking agent, $c a .2 \mathrm{ml}$ of $0.25 \mathrm{~mol} \mathrm{l}^{-1}$ EDTA and $3 \mathrm{ml}$ of 1 mol $\mathrm{l}^{-1}$ sodium fluoride were used for $100 \mathrm{ml}$ of sample solution containing $0.25 \mathrm{mg} \mathrm{l}^{-1}$ palladium and $250 \mathrm{mg} \mathrm{l}^{-1}$ interfering element. Results have been shown in Table 2.

As can be seen from Table 2, the recovery of palladium is still low in the presence of nickel and iron. Although the retention of nickel on the XAD-16 was about $4 \%$ at pH $2,{ }^{29}$ large amounts of nickel in the sample solution results in high nickel concentration in the elution solution. So, nickel could interfere with the absorption of palladium in flame processes. The effect of many transition elements on the signal of palladium can be prevented by addition of $0.5 \%(\mathrm{~m} / \mathrm{v})$ cadmium, copper or lanthanum solutions into sample and calibration solutions. ${ }^{25,26}$ Thus, $0.5 \mathrm{ml}$ of $0.5 \%(\mathrm{~m} / \mathrm{v})$ copper solution has been added to the sample and calibration solutions after preconcentration procedure to prevent the nickel and iron interferences. As can be seen from Table 2 , recovery of palladium is quantitative by using EDTA and copper.

\section{Application}

A standard reference metarial (a lead based alloy, NBS 53e) was prepared described above and palladium was preconcentrated and determined by the developed method. The limit of detection was calculated on the basis of three times the standard deviation of the absorbance using a series of measurements of blank solutions prepared according to the
Table 2 Effect of matrix elements $\left(250 \mathrm{mg} \mathrm{l}^{-1}\right)$ on recovery of palladium $\left(0.25 \mathrm{mg} \mathrm{l}^{-1}\right)$

\begin{tabular}{ccc}
\hline Element & Reagents used & $\begin{array}{c}\text { Recovery of } \\
\text { palladium, \% }\end{array}$ \\
\hline $\mathrm{None}$ & - & 98 \\
$\mathrm{Fe}$ & - & 20 \\
$\mathrm{Fe}$ & $\mathrm{EDTA}$ & 90 \\
$\mathrm{Fe}$ & EDTA and $\mathrm{Cu}$ & 98 \\
$\mathrm{Fe}$ & $\mathrm{NaF}$ & 91 \\
$\mathrm{Cu}$ & - & Not determined \\
$\mathrm{Cu}$ & EDTA & 97 \\
$\mathrm{Ni}$ & - & 50 \\
$\mathrm{Ni}$ & $\mathrm{EDTA}$ & 76 \\
$\mathrm{Ni}$ & $\mathrm{EDTA}$ and Cu & 90 \\
$\mathrm{Na}$ & - & 85 \\
$\mathrm{~K}$ & - & 95 \\
$\mathrm{Ca}$ & - & 94 \\
$\mathrm{Mg}$ & - & 83 \\
\hline
\end{tabular}

\begin{tabular}{|c|c|c|c|c|}
\hline \multirow{2}{*}{ Sample } & \multicolumn{2}{|c|}{ Palladium/mg $\mathrm{l}^{-1}$} & \multirow[b]{2}{*}{$\begin{array}{l}\text { Relative } \\
\text { error, \% }\end{array}$} & \multirow[b]{2}{*}{$\begin{array}{c}\text { L.O.D }{ }^{\mathrm{b}} / \\
\mathrm{mg} \mathrm{l}^{-1}\end{array}$} \\
\hline & Added & Found $^{\mathrm{a}}$ & & \\
\hline NBS $53 \mathrm{e}^{\mathrm{c}}$ & 2.50 & $2.36 \pm 0.03$ & -5.68 & 0.051 \\
\hline
\end{tabular}

Table 3 Determination of palladium in lead base alloy (NBS 53e)

a. Average of six determinations with $95 \%$ confidence level.

b. Limit of dedection based on $99.7 \%(3 \sigma)$ confidence level $(N=16)$.

c. The composition of NBS 53e $(\mathrm{m} / \mathrm{m} \%): \mathrm{Pb}, 84.00 ; \mathrm{Sb}, 10.26 ; \mathrm{Cu}$, 0.054 ; Ni, 0.003; As, 0.057; Sn, 5.84; Bi, 0.052; Fe, <0.001.

procedure given under sample preparation without taking the sample (Table 3). As can be seen, trace amounts of palladium could be determined with the relative error is $5.68 \%$ in lead based alloy.

\section{Conclusion}

A simple and reproducible method for the determination of trace amounts of palladium has been developed and applied successfully to the analysis of alloy. The Amberlite XAD-16 column provides a simple and reliable but somewhat timeconsuming technique for the separation and preconcentration of palladium.

\section{References}

1. D. L. Tsalev and V. I. Slaveykova, J. Anal. At. Spectrom., 1992, 7, 147.

2. O. Acar, A. R. Türker, and Z. Kılıç, Fresenius' J. Anal. Chem., 1998, 360, 645.

3. R. Gaita and S. J. Al-Bazi, Talanta, 1995, 42, 249.

4. D. M. Wayne, J. Anal. At. Spectrom., 1997, 12, 1195.

5. A. G. Coedo, M. T. Dorado, I. Padilla, and F. Alguacil, Anal. Chim. Acta, 1997, 340, 31.

6. I. Jarvis, M. M. Totland, and K. E. Jarvis, Analyst [London], 1997, 122, 19.

7. H. Minamisawa, Y. Tatehaba, N. Arai, and T. Okutani, Anal. Sci., 1996, 12, 947. 
8. R. Sahu, S. M. Sondhi, and B. Gupta, Talanta, 1995, 42 , 401.

9. K. Watanabe, M. Hojjatie, S. Imai, and S. Kobayashi, Anal. Sci., 1989, 5, 419.

10. K. Saito and H. Freiser, Anal. Sci., 1989, 5, 583.

11. J. Gao, B. Peng, H. Fan, J. Kang, and X. Wang, Talanta, 1997, 44, 837.

12. I. Kasahara, I. Tachi, E. Tsuda, N. Hata, S. Taguchi, and K. Goto, Analyst [London], 1989, 114, 1479.

13. H. Ishii, M. Minegishi, and T. Odashima, Anal. Sci., 1991, 7,73 .

14. Z. Liu, W. Chang, J. Hong, and Y. Ci, Analyst [London], 1991, 116, 213.

15. L. Po, L. Hengchuan, and W. Cheng, Talanta, 1991, 38, 1143.

16. H. Zhang, W. Mou, and J. Cheng, Talanta, 1994, 41, 1459.

17. G. V. Murthy and T. S. Reddy, Talanta, 1992, 39, 697.

18. A. Ramesh, Talanta, 1994, 41, 355.

19. L. Elçi, S. Işildar, and M. Doğan, Anal. Chim. Acta, 1994, 293,319

20. S. Hoshi, K. Higashihara, M. Suzuki, Y. Sakurada, K.
Sugawara, M. Uto, and K. Akatsuka, Talanta, 1997, 44, 571.

21. K. C. Thomson and R. J. Reynolds, "Atomic Absorption, Fluorescence and Flame Emission Spectroscopy, A Practical Approach", 1978, Charles Griffin and Company Ltd., England.

22. Y. Hasegawa, I. Kobayashi, and A. Okuda, Anal. Sci., 1991, 7, 377

23. S. Srivastava and G. N. Rao, Analyst [London], 1990, 115, 1607.

24. S. Balani and B. K. Puri, Talanta, 1992, 39, 815.

25. P. J. Whiteside and B. A. Milner. "Pye Unicam Atomic Absorption Data Book", 1984, Pye Unicam Ltd., Cambridge.

26. B. Welz, "Atomic Absorption Spectrometry", 1985, Federal Republic of Germany, Weinheim.

27. A. W. Adamson, "Physical Chemistry of Surfaces", 1990 Wiley Interscience, New York, 424.

28. S. Hoshi, H. Fujisawa, K. Nakamura, S. Nakata, M. Uto, and K. Akatsuka, Talanta, 1994, 41, 503.

29. A. R. Türker and A. Tunçeli, Fresenius' J. Anal. Chem., 1993, 345, 755 . 